\title{
A POSSIBLE MECHANISM FOR RELAXATION OF RAT UTERINE SMOOTH MUSCLE BY NICARDIPINE HYDROCHLORIDE (YC-93), A NEW POTENT VASODILATOR
}

\author{
Koji NISHIKORI, Toichi TAKENAKA* and Hiroo MAENO \\ Department of Pharmacology and Biochemistry. Central Research Laboratories. \\ Yamanouchi Pharmaceutical Co. Ltd., Itabashi-ku, Tokyo 174, Japan
}

Accepted April 29, 1981

\begin{abstract}
A new potent vasodilator, nicardipine hydrochloride inhibited oxytocin-induced contraction of rat uterus dose-dependently with an increase in the intracellular cyclic AMP level at the onset of relaxation. Dibutyryl cyclic AMP and papaverine, an inhibitor of cyclic AMP phosphodiesterase (PDEase), also inhibited the contraction. Nicardipine inhibited competitively PDEase in homogenates of rat uterus which exhibited apparently two $\mathrm{Km}$ values for cyclic AMP $(3.6 \mu \mathrm{M}$ and $67.3 \mu \mathrm{M})$ with the Ki of $5.3 \mu \mathrm{M}$ and $13.2 \mu \mathrm{M}$, respectively, but had no effect on adenylate cyclase. Nicardipine enhanced calcium uptake by rat uterine microsomes, at concentrations which inhibited oxytocin-induced contraction in the same manner as cyclic AMP. The maximal stimulation by nicardipine of the microsomal calcium uptake was identical substantially to that by cyclic AMP, and both were not additive. Cyclic AMP was also accumulated during the uptake reaction in the presence of nicardipine. On the contrary. neither myosin ATPase nor microsomal $\mathrm{Ca}^{2+}$-dependent ATPase was inhibited directly by nicardipine. These results suggest that the inhibition of oxytocin-induced contraction of rat uterus by nicardipine may be due to an enhancement of microsomal calcium uptake, mediated by cyclic AMP accumulated through the inhibition of PDEase.
\end{abstract}

It has been demonstrated that a 1.4dihydropyridine derivative, 2,6-dimethyl-4(3-nitrophenyl) -1,4-dihydropyridine-3,5-

dicarboxylic acid 3-[2-(N-benzyl-N-methylamino)] ethyl ester hydrochloride (nicardipine hydrochloride, YC-93. Fig. 1) was 100 times as potent as other vasodilating drugs such as papaverine, isoxsuprine or cinnarizine, in causing dilation of cerebral and coronary arteries (1, 2). The pharmacological characteristics of nicardipine suggest a direct action of the drug on vascular smooth muscle without acting through specific receptors.

*To whom reprint requests should be addressed.
Sakamoto et al. (3) reported that nicardipine is a potent inhibitor of cyclic AMP phos-

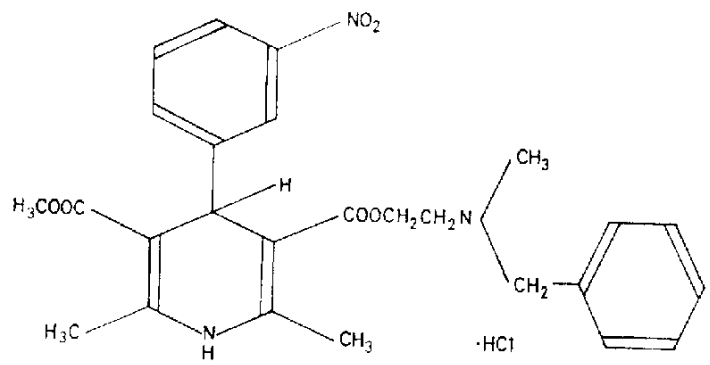

Fig. 1. Chemical structure of nicardipine hydrochloride (YC-93), 2.6-dimethyl-4-(3-nitrophenyl)-1,4-dihydropyridine-3,5-dicarboxylic acid 3-[2-(N-benzyl-N-methylamino)]ethyl ester hydrochloride. 
phodiesterase (PDEase) with an increase in a cyclic AMP level in the coronary artery. To elucidate the biochemical mechanism for relaxation of smooth muscle induced by nicardipine, we focussed our attention on the effect of the drug on calcium uptake by microsomes isolated from rat uterus, in relation with cyclic AMP. We have already found the stimulation by cyclic AMP of rat uterine microsomal calcium uptake under appropriate conditions $(4,5)$, and the uterine microsomes have the ability to accumulate sufficient amounts of calcium to regulate contraction of smooth muscle (6-8). The present work is a description of the stimulation by nicardipine of microsomal calcium uptake which may trigger the relaxation of rat uterus.

\section{MATERIALS AND METHODS}

Materials: Cyclic AMP and Millipore filter disks were obtained from Boehringer/ Mannheim-Yamanouchi and Millipore Japan. respectively. Nicardipine was prepared in our laboratories. [ $\left.{ }^{3} \mathrm{H}\right] \mathrm{Cyclic}$ AMP $(27 \mathrm{Ci}$ ) mole) and ${ }^{45} \mathrm{CaCl}_{2}$ (2 $\mathrm{Ci} /$ mole $)$ were purchased from New England Nuclear. [ $\gamma$ 32P]ATP $(12 \mathrm{Ci} / \mathrm{mole})$ was prepared by the method of Post and Sen (9).

Animals: Virgin female Sprague-Dawley rats (200 to $250 \mathrm{~g}$ ) in estrus, as determined by vaginal smear examination, were decapitated and the uterus was quickly removed and cleaned of fat and connective tissue.

Determination of isometric contraction of isolated rat uterus: Contraction of the isolated uterus was determined by a slight modification of the method of Mitznegg et al. (10). An isolated strip of rat uterus was suspended in Tyrode's solution bubbled with $95 \% \mathrm{O}_{2}-5 \%$ $\mathrm{CO}_{2}$ mixture gas at $37^{\circ} \mathrm{C}$. The solution contained $137 \mathrm{mM} \mathrm{NaCl}, 2.7 \mathrm{mM} \mathrm{KCl}, 1.1$ $\mathrm{mM} \mathrm{MgCl} 2,1.8 \mathrm{mM} \mathrm{CaCl}_{2}, 0.42 \mathrm{mM} \mathrm{NaH}_{2}-$ $\mathrm{PO}_{4}, 11.9 \mathrm{mM} \mathrm{NaHCO}_{3}$ and $5.5 \mathrm{mM}$ glucose. The strip was gently stretched until a steady base-line tension of $1 \mathrm{~g}$ was reached. The contraction was induced by 1 USP munit/ml of oxytocin, and the contractile response was recorded isometrically for at least $15 \mathrm{~min}$ by a strain gauge transducer connected to a Nihon Kohden polygraph, model RM-150. When the effect of the drugs on contraction was studied, oxytocin was removed by washing with Tyrode's solution. Following incubation of the tissue with the drugs for 10 min, oxytocin was applied and the contractile response was recorded. A height of each maximal contractile response before $\left(h_{1}\right)$ and after $\left(h_{2}\right)$ addition of the drugs was measured, and the percentage inhibition of oxytocin-induced contraction was calculated as $\left(h_{1}-h_{2}\right) / h_{1} \times 100(\%)$. Ninety minutes after removal of oxytocin and the drugs by washing with Tyrode's solution, the uterus could still respond to oxytocin in the same manner.

Preparation of microsomes: The microsomal fractions were prepared from rat uterus at $4^{\circ} \mathrm{C}$ as described previously $(4,5)$. The cleaned uteri $(10 \mathrm{~g})$ were homogenized with a Polytron homogenizer (KINEMATICA) in $90 \mathrm{ml}$ of ice-cold $0.33 \mathrm{M}$ sucrose containing $10 \mathrm{mM}$ histidine/ $\mathrm{HCl}$ buffer, $\mathrm{pH}$ 6.8. The homogenate was centrifuged at $12.000 \times \mathrm{g}$ for $20 \mathrm{~min}$ and the supernatant was further centrifuged at $105,000 \times \mathrm{g}$ for $60 \mathrm{~min}$. The resulting pellet (50 $\mathrm{mg}$ of protein) was used for the microsomal fractions after resuspension in $20 \mathrm{mM}$ histidine/ $\mathrm{HCl}, \mathrm{pH} 6.8$. These microsomal preparations were virtually devoid of the activity of succinic dehydrogenase as a marker for mitochondria as determined by the method described previously (4).

Protein was determined by the method of Lowry et al. (11) with bovine serum albumin as a standard.

Standard assay for microsomal calcium uptake: Calcium uptake by rat uterine microsomes was determined as described in the 
previous papers $(4,5)$. Freshly prepared microsomes (100 to $200 \mu \mathrm{g}$ of protein) were preincubated for $1 \mathrm{~min}$ at $25^{\circ} \mathrm{C}$ in a total volume of $0.2 \mathrm{ml}$ containing $120 \mathrm{mM} \mathrm{KCl}$, $2.5 \mathrm{mM}$ Tris/oxalate, $250 \mu \mathrm{M}$ ATP. $500 \mu \mathrm{M}$ $\mathrm{MgCl}_{2}$ and $10 \mathrm{mM}$ histidine $/ \mathrm{HCl}$ buffer. $\mathrm{pH}$ 6.8. The calcium uptake reaction was started by addition of ${ }^{45} \mathrm{Ca} / \mathrm{EGTA}$ buffer containing $125 \mu \mathrm{M}^{45} \mathrm{CaCl}_{2}(0.4 \mathrm{Ci} /$ mole) and $391 \mu \mathrm{M}$ EGTA [the calculated concentration of free calcium is $1 \mu \mathrm{M}(12)]$. After 1 min of the incubation at $25^{\circ} \mathrm{C}$ the uptake reaction was stopped by passing through a Millipore HA $(0.45 \mathrm{~nm})$ filter disk under vacuum upon addition of $2 \mathrm{ml}$ of ice-cold ${ }^{45} \mathrm{Ca} / \mathrm{EGTA}$-free medium. The filter disk was then washed 3 times with $2 \mathrm{ml}$ of the ${ }^{45} \mathrm{Ca} / \mathrm{EGTA}$-free medium. The radioactivity on the filter disk was counted using Bray's scintillator (13).

Assay for PDEase activity: PDEase activity was determined by the method of Terai et al. (14). The standard incubation mixture with a total volume of $0.5 \mathrm{ml}$ contained $30 \mathrm{mM}$ Tris/ $\mathrm{HCl}, \mathrm{pH} 7.5,5 \mathrm{mM} \mathrm{MgCl}, 1 \mathrm{mM} 2-$ mercaptoethanol, $100 \mathrm{mM} \mathrm{NaCl}, 0.5$ to $20 \mu \mathrm{M}$ [3 H]cyclic AMP (1 to $10 \mathrm{Ci} / \mathrm{mole}), 50 \mu \mathrm{g}$ of bovine serum albumin and an appropriate amount of the enzyme. The homogenates of rat uterus were employed as the enzyme solution. Incubations were carried out for $5 \mathrm{~min}$ at $37^{\circ} \mathrm{C}$ and stopped by placing the test tube in a boiling bath for 2 min. The reaction mixture was cooled and further incubated for $30 \mathrm{~min}$ at $37^{\circ} \mathrm{C}$ after addition of $50 \mu \mathrm{g}$ Naja heja snake venom as a source of $5^{\prime}$-nucleotidase in order to convert completely [3 $\mathrm{H}]-5^{\prime}$-AMP formed during the incubation into $\left[{ }^{3} \mathrm{H}\right]$ adenosine. Following addition of $0.5 \mathrm{ml}$ of $0.5 \mathrm{mM}$ carrier adenosine the total mixture was applied to a Dowex-1 (Clform) column $(0.7 \times 2.0 \mathrm{~cm})$. Adenosine eluted with $0.1 \mathrm{M}$ Tris $/ \mathrm{HCl}, \mathrm{pH}$ 7.5, was determined by counting its radioactivity.

Assay for adenylate cyclase and cyclic AMP-dependent protein kinase: Adenylate cyclase activity in rat uterine microsomal preparations was measured by the method of Kebabian et al. (15) by measuring the amount of cyclic AMP formed in each assay tube by the binding method of Brown et al. (16)

Protein kinase activities in the microsomal fractions were determined by measuring the incorporation of ${ }^{32} \mathrm{Pi}$ from $\left[\gamma-{ }^{32} \mathrm{P}\right] \mathrm{ATP}$ into histones by the method of Maeno et al. (17) and into a endogenous membrane-bound protein. Protein A as described previously (5).

Assay for ATPase activities: Myosin ATPase activity was measured using purified uterine myosin according to Perry (18). Rat uterus was homogenized with a Polytron homogenizer (KINEMATICA) in 3-volume of Guba-Straub solution (19). Myosin was purified through the repeat of precipitation and solubilization by changing the salt concentration (18).

$\mathrm{Ca}^{2+}$-ATPase activity in the microsomal fractions was assayed by measuring $[\gamma$ 32P]ATP hydrolysis by the method of described previously (5). $\mathrm{Ca}^{2+}$-activated activity was obtained from the difference between the amounts of $\mathrm{Pi}$ generated in the presence and absence of $100 / 2 \mathrm{M} \mathrm{Ca}^{2+}$ in the incubation.

\section{RESULTS}

Antagonistic effect of nicardipine on oxytocin-induced contraction of rat uterus: Nicardipine inhibited oxytocin-induced contraction of rat uterus and relaxed strips of this organ. Figure 2 shows a typical chart of the contraction induced by 1 USP munit/ml oxytocin and the antagonistic effect of nicardipine at $0.3 \mu \mathrm{M}$. Dibutyry| cyclic AMP and papaverine, an inhibitor of PDEase as well as nicardipine inhibited the contraction of rat uterine smooth muscle. Ninety minutes after removal of oxytocin and the drugs by washing with Tyrode's solution, it was ascertained that the uterus could still respond 

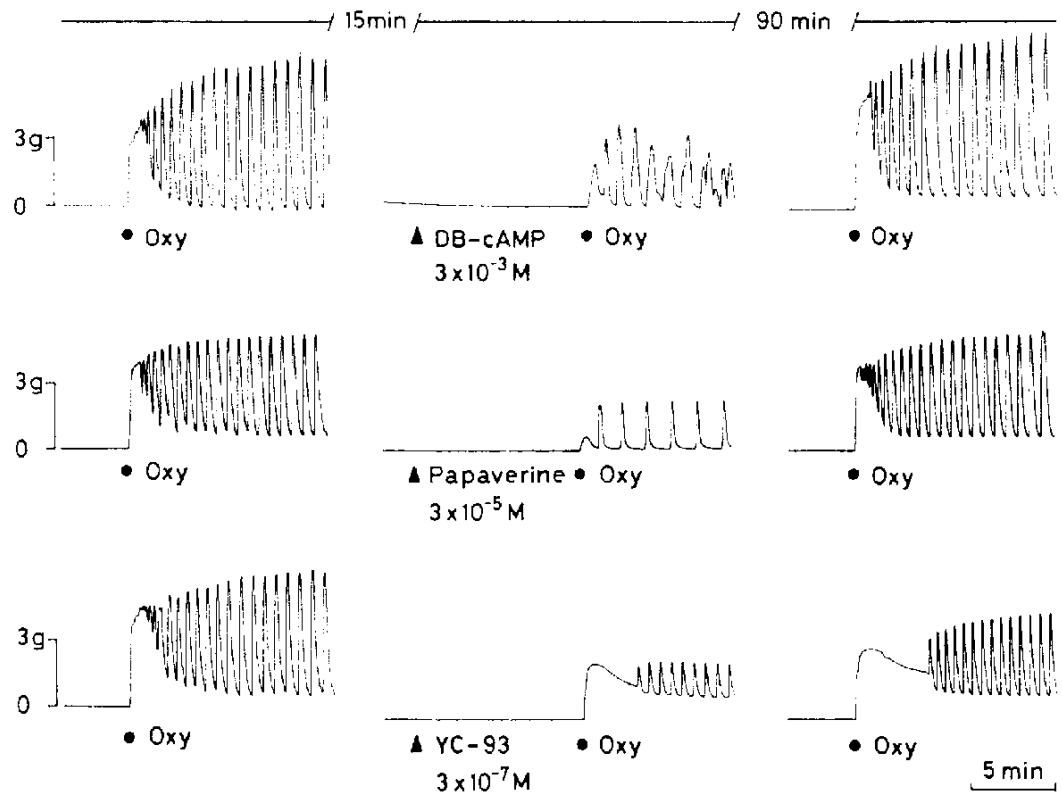

Fig. 2. Tracing of isometric contraction of isolated rat uterus induced by 1 USP munit/ml oxytocin and the antaginizing effects of $0.3 \mu \mathrm{M}$ nicardipine (YC-93). $30 \mu \mathrm{M}$ papaverine and $3 \mathrm{mM}$ dibutyryl cyclic AMP (DB-cAMP). Experimental procedures are described in the text. $O x y=1$ USP munit/ml oxytocin.

to oxytocin as normally as before. The effects of the drugs were dose-dependent as shown in Fig. 3. The estimated concentrations of nicardipine, papaverine and dibutyryl cyclic AMP required for $50 \%$ inhibition of oxytocininduced contraction were approx. $0.3 \mu \mathrm{M}$, $50 \mu \mathrm{M}$ and $3 \mathrm{mM}$, respectively. Neither dibutyryl cyclic GMP nor butyric acid produced a significant inhibition under the same conditions.

The amount of cyclic AMP in the tissue was determined at the onset of inhibition by the drugs of oxytocin-induced uterine contraction. As shown in Table 1, nicardipine and papaverine produced a significant increase in the intracellular cyclic AMP level at the concentrations which could inhibit the contraction.

These results suggest that cyclic AMP may be involved in the uterine relaxation.

Effects of nicardipine on PDEase, adenylalte cyclase and cyclic AMP-dependent protein kinase activities: Consistent with the increase by nicardipine in the intracellular

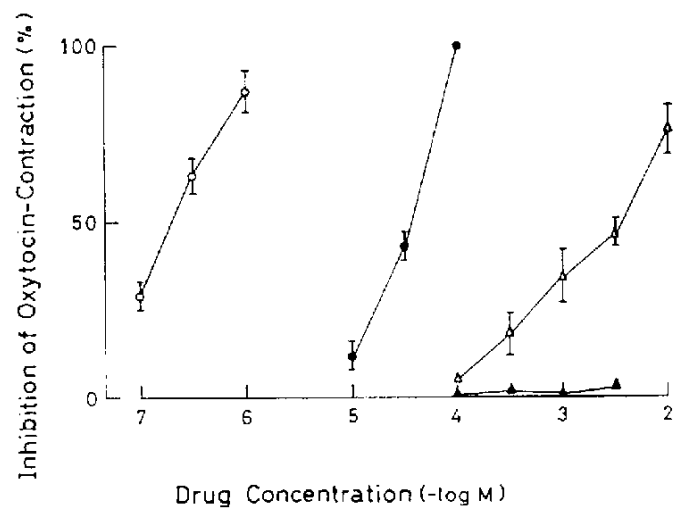

Fig. 3. Dose response curves for the effects of nicardipine (O), papaverine (O), dibutyryl cyclic AMP $(\triangle)$ and dibutyryl cyclic GMP $(\mathbf{\Lambda})$ on oxytocin-induced contraction of isolated rat uterus. Experimental procedures are described in the text. Each point represents mean percentage inhibition of the contraction and vertical bar shows the standard error for five experiments. 
Table 1. Increase in cyclic AMP contents in rat uterus at the onset of relaxation induced by nicardipine. Tow crescent strips were separated from one uterus, and each was incubated at $37^{\circ} \mathrm{C}$ for $10 \mathrm{~min}$ in Tyrode's solution in the absence and presence of $1 \mu \mathrm{M}$ nicardipine (Experiment 1) or $100 \mu \mathrm{M}$ papaverine (Experiment 2), respectively. The amoun of cyclic AMP in each tissue was determined by the protein binding method of Sakamoto et al. (3) after homogenization of the tissue with $3 \%$ trichloroacetic acid following removal of protein and neutralization. Results are given as meantstandard errors for the nine determinations

\begin{tabular}{|c|c|c|c|c|}
\hline Addition & & $\begin{array}{l}\text { Cyclic AMP contents } \\
\text { (pmol/mg protein) }\end{array}$ & $\%$ of control & $\mathrm{P}$ \\
\hline \multicolumn{5}{|l|}{ Experimerit 1} \\
\hline None & & $54.5 \pm 5.1$ & 100 & - \\
\hline Nicardipine & $0.1 \mu \mathrm{M}$ & $71.2 \pm 3.9$ & 131 & $p<0.01$ \\
\hline & $1 \mu \mathrm{M}$ & $75.4 \pm 7.7$ & 139 & $p<0.01$ \\
\hline \multicolumn{5}{|l|}{ Experiment 2} \\
\hline None & & $65.6 \pm 6.6$ & 100 & - \\
\hline \multirow[t]{2}{*}{ Papaverine } & $10 \mu \mathrm{M}$ & $72.3 \pm 7.4$ & 110 & $\left.N S^{a}\right)$ \\
\hline & $100 \mu \mathrm{M}$ & $87.9 \pm 8.5$ & 134 & $p<0.01$ \\
\hline
\end{tabular}

a) NS, not significant.

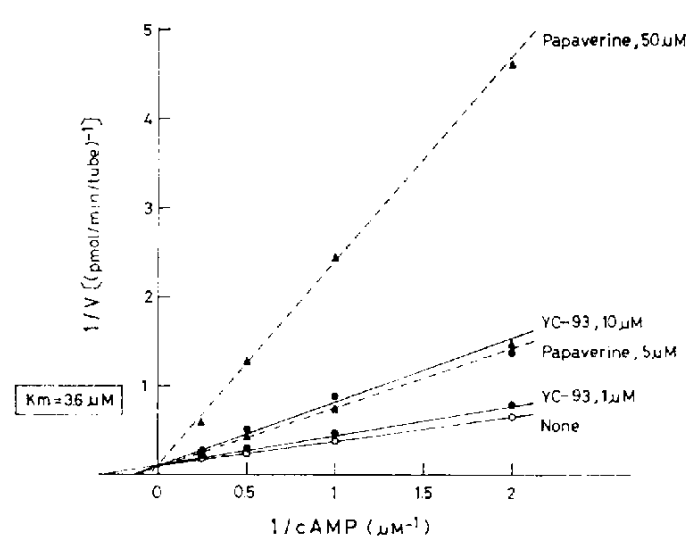

Fig. 4. Double reciprocal plot of the low $\mathrm{Km}$ activity of PDEase. The activity was determined under the standard conditions in the presence of $0.5,1,2$ and $4 \mu \mathrm{M}\left[{ }^{3} \mathrm{H}\right]$ cyclic AMP with nicardipine (YC-93) and papaverine at the indicated concentrations. Each point represents mean value of triplicate determinations.

cyclic AMP level of the uterine smooth muscle, we found that the drug inhibited markedly PDEase of the uterus in a competitive manner. The two types of the enzyme activity were present in the homogenate preparations of rat uterus differed in the affinities to cyclic AMP, i.e. the apparent

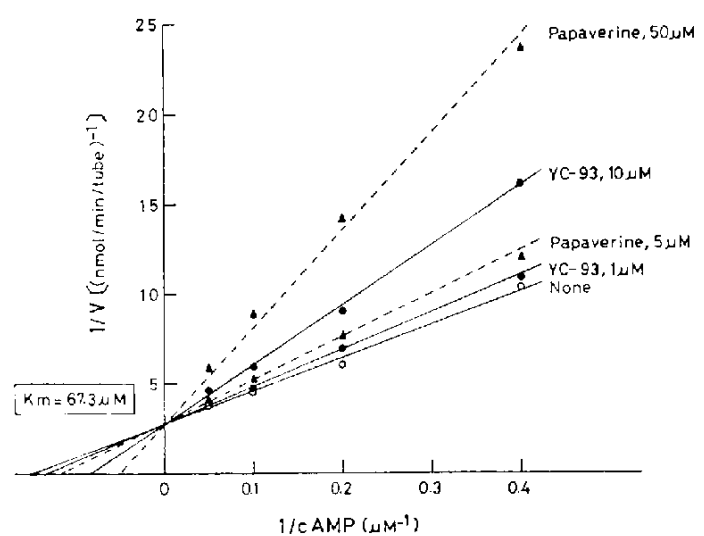

Fig. 5. Double reciprocal plot of the high $\mathrm{Km}$ activity of PDEase. The activity was determined under the standard condition in the presence of 2.5, 5, 10 and $20 \mu \mathrm{M}\left[{ }^{3} \mathrm{H}\right]$ cyclic AMP with nicardipine (YC-93) and papaverine at the indicated concentrations. Each point represents mean value of triplicate determinations.

affinity constant $(\mathrm{Km})$ values for cyclic AMP were $3.6 \mu \mathrm{M}$ and $67.3 \mu \mathrm{M}$. In the case of low $\mathrm{Km}$ activity, the apparent inhibition constant (Ki) value for nicardipine was $5.3 \mu \mathrm{M}$ and for papaverine $7.1 \mu \mathrm{M}$. In high $\mathrm{Km}$ activity, the $\mathrm{Ki}$ values for nicardipine and papaverine were $13.2 \mu \mathrm{M}$ and $30.3 \mu \mathrm{M}$, 
respectively (Figs. 4 and 5 ).

On the other hand, nicardipine had no significant influence on both basal and $\mathrm{NaF}$ stimulated activities of adenylate cyclase of rat uterine microsomal preparations at the concentrations of 1 and $10 \mu \mathrm{M}$ (the activities in the absence and presence of $10 \mathrm{mM} \mathrm{NaF}$ were $15.8 \pm 2.6$ and $30.7 \pm 5.9$ pmol of cyclic AMP formed $/ \mathrm{min} / \mathrm{mg}$ of protein, respectively). Nicardipine slightly inhibited the activities only at a concentration as high as $100 \mu \mathrm{M}$.

Cyclic AMP-dependent protein kinase activities were not inhibited either by nicardipine at the concentrations inhibiting PDEase, as determined by using not only histone but also an endogenous membranebound protein. Protein A as a substrate $(4,5)$.

Effect of nicardipine on microsomal calcium uptake: It has been demonstrated that rat uterine microsomal calcium uptake is stimulated by cyclic AMP $(4,5)$ ), thus effects of nicardipine on uterine microsomal calcium uptake were also studied. Nicardipine and papaverine enhanced the microsomal calcium uptake in a dose-dependent manner as shown in Table 2. No additive effect of the drugs was found on the maximal uptake obtained by
$5 \mu \mathrm{M}$ cyclic AMP. implying that nicardipine and papaverine may mimic the action of cyclic AMP. The amount of cyclic AMP in the uptake reaction mixture was elevated dose-dependently by the drugs during the incubation (Fig. 6).

Effects of nicardipine on myosin ATPase activity and microsomal $\mathrm{Ca}^{2+}$-activated ATPase activity: Table 3 shows that nicardipine at 1 and $10 \% \mathrm{M}$ and papaverine at 10 and $100 \mu \mathrm{M}$ had no significant effect of ATPase activity in uterine purified myosin.

$\mathrm{Ca}^{2+}$-activated ATPase activity was determined in uterine microsomes in the absence and presence of $100 \mu \mathrm{M} \mathrm{Ca}{ }^{2+}$. Neither nicardipine at 1 to $100 \mu \mathrm{M}$ nor papaverine at $100 \mu \mathrm{M}$ had any significant effect on the activities in the absence or presence of $\mathrm{Ca}^{2+}$.

\section{DISCUSSION}

Nicardipine, a new potent vasodilator (1, 2) antagonizes oxytocin-induced contraction of rat uterine smooth muscle in the same manner as dibutyryl cyclic AMP and papaverine, an inhibitor of PDEase. The cyclic AMP levels in the tissue increase at the onset of the relaxation. The accumulation

Table 2. Stimulation of rat uterine microsomal calcium uptake by nicardipine and papaverine. Microsomal calcium uptake was determined under the standard conditions, except for the presence of the indicated drugs. Results are given as means \pm standard errors for six determinations

\begin{tabular}{lcc}
\hline Addition & $\mu \mathrm{M}$ & $\begin{array}{c}\text { Microsomal calcium uptake } \\
\text { (nmole/min/mg protein) }\end{array}$ \\
\hline None & - & $0.561 \pm 0.080$ \\
Cyclic AMP & 5 & $1.16 \pm 0.11$ \\
Nicardipine & 0.01 & $0.602 \pm 0.108$ \\
& 0.1 & $0.641 \pm 0.058$ \\
Papaverine & 1 & $0.949 \pm 0.133$ \\
& 10 & $1.31 \pm 0.10$ \\
Cyclic AMP+Nicardipine, $5+10$ & $0.663 \pm 0.088$ \\
Cyclic AMP+Papaverine, $5+100$ & $0.884 \pm 0.117$ \\
\hline
\end{tabular}




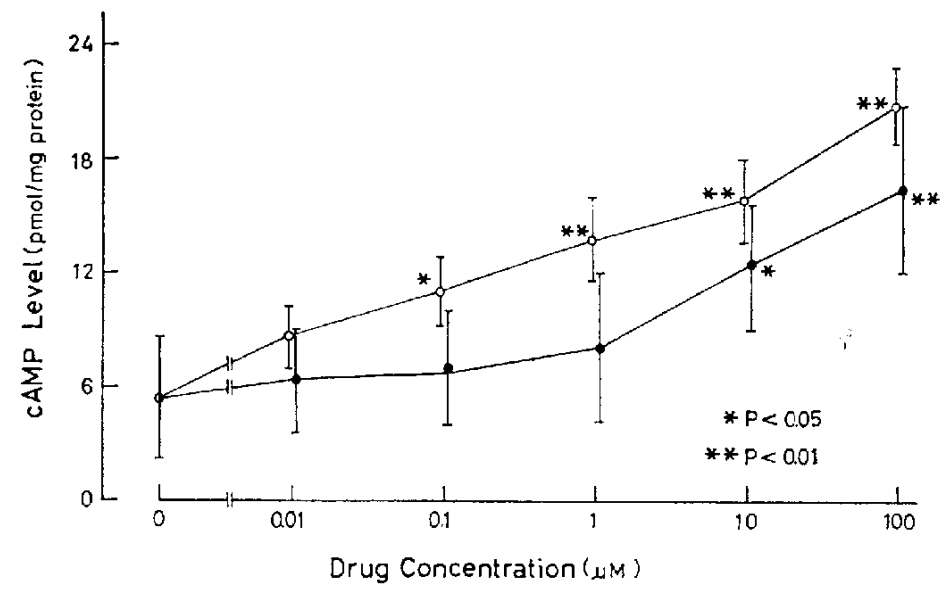

Fig. 6. Effects of nicardipine (O) and papaverine (O) on cyclic AMP level in the reaction mixture of calcium uptake. Amounts of cyclic AMP in the reaction mixture of calcium uptake were determined by the protein binding method (3). Each point represents mean cyclic AMP concentration and vertical bar shows the standard error for six experiments.

Table 3. Effects of nicardipine and papaverine on activities of myosin ATPase and microsomal $\mathrm{Ca}^{2+}$-dependent ATPase in rat uterine smooth muscle. Myosin ATPase and microsomal $\mathrm{Ca}^{2+}$-dependent ATPase activities were determined in the absence and presence of the indicated drugs. Results are given as means \pm standard errors for four determinations.

\begin{tabular}{|c|c|c|c|c|}
\hline \multirow{2}{*}{ Addition } & & \multirow{2}{*}{ Myosin ATPase } & \multicolumn{2}{|c|}{ Microsomal $\mathrm{Ca}^{2+}$-dependent ATPase } \\
\hline & & & Without $\mathrm{Ca}^{2+}$ & With $\mathrm{Ca}^{2+}$ \\
\hline & $\mu \mathrm{M}$ & $\underset{\text { protein }}{\mathrm{pmol} / \mathrm{min} / \mathrm{mg}}$ & \multicolumn{2}{|c|}{$\mathrm{pmole} / \mathrm{min} / \mathrm{mg}$ protein } \\
\hline None & & $41.4 \pm 9.8$ & $11.8 \pm 2.3$ & $27.9 \pm 2.5$ \\
\hline \multirow[t]{3}{*}{ Nicardipine } & 1 & $38.3 \pm 8.7$ & $10.9 \pm 1.4$ & $28.1 \pm 3.2$ \\
\hline & 10 & $34.9 \pm 7.3$ & $11.9 \pm 3.5$ & $26.2 \pm 2.7$ \\
\hline & 100 & $44.2 \pm 6.6$ & $12.4 \pm 1.9$ & $29.3 \pm 2.4$ \\
\hline \multirow[t]{2}{*}{ Papaverine } & 10 & $39.8 \pm 8.1$ & $13.4 \pm 2.8$ & $27.5 \pm 4.3$ \\
\hline & 100 & $35.7 \pm 7.4$ & $13.6 \pm 5.2$ & $28.6 \pm 3.2$ \\
\hline
\end{tabular}

of cyclic AMP implies that nicardipine mimics the action of this nucleotide. Since nicardipine has a potent inhibitory effect on PDEase but neither adenylate cyclase nor cyclic AMP-dependent protein kinase in the preparations of rat uterus at concentrations which inhibit the contraction, the accumulation of cyclic AMP in the tissue by the drug is mainly due to the inhibition of PDEase. Our previous studies also demonstrated that nicardipine is a potent inhibitor of several DPEases (3). Our present work demonstrated that nicardipine has the ability to stimulate the microsomal calcium uptake under the same conditions as those required for the stimulation by cyclic AMP, as described previously $(4,5)$. The stimulation of microsomal calcium uptake may be mediated by cyclic AMP-enhanced endogenous phosphorylation of a specific membrane-bound protein, Protein A (5). It is likely that the enhancement of the 
microsomal calcium uptake triggers the relaxation of uterine smooth muscle (6-8).

Papaverine a nonspecific smooth muscle relaxant and an inhibitor of PDEase has effects similar to those of nicardipine on the microsomal calcium uptake. It has been reported that papaverine inhibits various PDEase activities and increases the intracellular cyclic AMP level in several kinds of smooth muscles (20-22). It was also demonstrated that an inhibitory potency of papaverine on PDEase activity of the preparations from several smooth muscles correlates closely with its relaxing activity on each muscle $(20,21)$. Carpendo et al. (23) reported that papaverine and eupaverine enhance the rate of calcium uptake significantly in the isolated microsomes from rabbit white skeletal muscle. It is of interest that papaverine stimulates calcium uptake by microsomes from skeletal muscle as well as from smooth muscle.

Myosin ATPase of uterine smooth muscle plays an important role in the regulation of the smooth muscle contractility, similar to the case of the enzyme of skeletal muscle (24. 25). Data shown in the present paper indicate that nicardipine has no direct significant effect on uterine myosin ATPase, suggesting that the relaxing effect of nicardipine on uterine smooth muscle is not due to an inhibition of the contractile apparatus directly.

We also found that $\mathrm{Ca}^{2+}$-ATPase of microsomes, which is assumed to couple with calcium uptake by sarcoplasmic reticulum $(26,27)$, is not significantly affected by nicardipine. These results, however, do not necessarily rule out the possibility that enhancement of the microsomal calcium uptake may be mediated by stimulation of $\mathrm{Ca}^{2+}$-ATPase as discussed in a previous report (5). Stimulation of $\mathrm{Ca}^{2+}$ ATPase coupling with microsomal calcium uptake is computed to be only less than $10 \%$ of the total $\mathrm{Ca}^{2+}$-ATPase activity in the microsomes since hydrolysis of one mole of ATP is able to transport two moles of $\mathrm{Ca}^{2+}$ (28). This increased amount of $\mathrm{Ca}^{2+}$-ATPase is virtually impossible to be detected with regard to total activities. It is not possible at present to distinguish $\mathrm{Ca}^{2+}$-ATPase which couples with the calcium transport from other kinds of $\mathrm{Ca}^{2+}$-ATPase.

Although the present studies confirm the involvement of cyclic AMP in the regulation of intracellular calcium movement in uterine smooth muscle as demonstrated previously $(4,5)$, there remains the possibility that the mode of action of nicardipine may be distinct in a smooth muscle, the contractility of which is mainly dependent upon extracellular calcium such as in the case of rabbit aorta (29). Our recent studies showed that nicardipine inhibits high $\mathrm{K}^{+}$-induced contraction of rabbit aortic smooth muscle with a concurrent inhibition of high $\mathrm{K}^{+}$induced influx of calcium through the plasma membranes (30).

Acknowledgement: We thank Miss. $Y$. Matsuda for excellent technical assistance.

\section{REFERENCES}

1) Takenaka, T., Usuda, S., Nomura, T., Maeno, $H$. and Sado, T: Vasodilator profile of a new 1.4-dihydropyridine derivative, 2,6-dimethyl-4(3-nitrophenyl) -1,4-dihydropyridine-3.5dicarboxylic acid 3-[2-(N-benzyl-N-methylamino)] ethyl ester 5 -methyl ester hydrochloride (YC-93). Arzneim.-Forsch 26, 2172-2178 (1976)

2) Takenaka, T. and Handa, J.: Cerebrovascular effects of YC-93, a new vasodilator, in dogs, monkeys and human patients. Int. J. Clin. Pharmacol. 17, 1-11 (1979)

3) Sakamoto, N., Terai, M., Takenaka, T. and Maeno, H.: inhibition of cyclic AMP phosphodiesterase by 2,6-dimethyl-4-(3-nitrophenyl)-1.4-dihydropyridine-3.5-dicarboxylic acid 3-[2-(N-benzyl-N-methylamino)]ethyl ester 5-methyl ester hydrochloride (YC-93). a potent vasodilator. Biochem. Pharmacol. 27, $1269-1274(1978)$ 
4) Nishikori, K., Takenaka, T. and Maeno, H.: Stimulation of microsomal calcium uptake and protein phosphorylation by adenosine $3^{\prime}, 5^{\prime}$ monophosphate in rat uterus. Mol. Pharmacol. 13, 671-678 (1977)

5) Nishikori, K. and Maeno, H.: Close relationship between adenosine 3',5'-monophosphate-dependent endogenous phosphorylation of a specific protein and stimulation of calcium uptake in rat uterine microsomes $\mathrm{J}$. biol. Chem. 254, 6099-6106 (1979)

6) Carsten, M.E.: Role of calcium binding by sarcoplasmic reticulum in the contraction and relaxation of uterine smooth muscle. J. gen. Physiol. 53, 414-426 (1969)

7) Batra, S.C. and Daniel, E.E.: Effect of multivalent cations and drugs on $\mathrm{Ca}$ uptake by the rat myometrial microsomes. Comp. Biochem. Physiol. 38A, 285-300 (1971)

8) Daniel,E.E. and Janis, R.A.: Calcium regulation in the uterus. Pharmacol. Ther. B. 1, 695-729 (1975)

9) Post, R.L. and Sen, A.K.: ${ }^{32} \mathrm{P}$-Labelling of a $\left(\mathrm{Na}^{+}+\mathrm{K}^{+}\right)$-ATPase intermediate. Methods Enzymol. 10, 773-776 (1967)

10) Mitznegg, P., Hach, B. and Meythaler, B.: Influence of endogenous and exogenous cyclic $3^{\prime} .5^{\circ}$-AMP on contractile response induced by oxytocin and calcium in isolated rat uterus. Life Sci. 9 Part I. 121-128 (1970)

11) Lowry, O.H., Rosebrough, N.J., Farr, A.L. and Randall, R.J.: Protein measurement with the Folin phenol reagent. J. biol. Chem. 193, 265-275 (1951)

12) Katz, A.M., Repke, D.I., Upshaw, J.E. and Polascik, M.A.: Characterization of dog cardiac microsomes. Use of zonal centrifugation to fractionate fragmented sarcoplasmic reticulum. $\left(\mathrm{Na}^{+}+\mathrm{K}^{+}\right)$-activated ATPase and mitochondrial fragments. Biochim. Biophys. Acta 205, 473490 (1970)

13) Bray, G.A.: A simple efficient liquid scintillator for counting aqueous solutions in a liquid scintillation counter. Anal. Biochem. 1, 279$285(1960)$

14) Terai, M., Furihata, C., Matsushima, T. and Sugimura, T.: Partial purification of adenosine $3^{\prime} .5^{\circ}$-cyclic monophosphate phosphodiesterase from rat pancreas in the presence of excess protease inhibitors. Arch. Biochem. Biophys. 176, 621-629 (1976)

15) Kebabian, J.W., Petzold, G.L. and Greengard, P.: Dopamine-sensitive adenylate cyclase in caudate nucleus of rat brain, and its similarity to the "dopamine receptor". Proc. natn. Acad. Sci. U.S.A. 69, 2145-2149 (1972)
16) Brown, B.L., Ekins, R.P. and Albano, J.D.M.: Saturation assay for cyclic AMP using endogenous binding protein. Adv. Cyclic Nucleotide Res. 2, 25-50 (1972)

17) Maeno, H., Johnson, E.M. and Greengard, P.: Subcellular distribution of adenosine $3^{x}, 5^{\prime}-$ monophosphate-dependent protein kinase in rat brain. J. biol. Chem. 264, 134-142 (1971)

18) Perry, S.V.: Myosin adenosinetriphosphatases. Methods Enzymol. 2, 582-588 (1955)

19) Guba, F. and Straub, F.B.: Reaction of adenosinetriphosphate with myosin. Studies Inst. Med. Chem. Univ. Szeged. 3, 46-52 (1943)

20) Triner, L., Hahas, G.G., Vulliemoz, Y., Overweg, N.I.A., Verosky, M.r Habif, D.V. and Nagai, S.H.: Crclic AMP and smooth muscle function. Ann. N.Y. Acad. Sci. 185, 458-476 (1971)

21) Poch, G. and Kukovetz, W.R.: Papaverineinduced inhibition of phosphodiesterase activity in various mammalian tissues. Life Sci. 10 , 133-144 (1971)

22) Inatomi, N., Takayanagi, I., Uchida, M. and Takagi, K.: Intracellular cyclic AMP level and intestinal smooth muscle relaxation. Europ. J. Pharmacol. 26. 73-76 (1974)

23) Carpendo, F., Toson, G.C., Furlanut, M. and Ferrari, M.: Effects of papaverine and eupaverine on calcium uptake by isolated saracoplasmic reticulum vesicles. J. Pharm. Pharmacol. 23, 502--505 (1970)

24) Wachsberger, P. and Kaldor, G.: Studies on uterine myosin $A$ and actomyosin. Arch. Biochem. Biophys. 143, 127-137 (1971)

25) Weeds, A.G. and Frank, G.: Structural studies on the light chains of myosin. Cold Spring Harbour Symp. Quant. Biol. 37, 9-14 (1972)

26) Carsten, M.E.: Hormonal antagonisms in the regulation of myometrial calcium transport. Gynecol. Invest. 5, 15-16 (1974)

27) Carsten, M.E.: The Biochemistry of Smooth Muscle, Edited by Newman, L.S., pp. 617-639. University Park Press, Baltimore (1977)

28) Entman, M.L., Snow, T.R., Freed, D. and Schwartz, A.: Analysis of calcium binding and release by canine cardiac relazing system (sarcoplasmic reticulum). J. biol. Chem. 248 , $7762-7772(1973)$

29) van Breemen, C., Farinas, B.R., Casteels, R., Gerba, P., Wuytack, F. and Deth, R.: Factors controlling cytoplasmic $\mathrm{Ca}^{2+}$ concentration. Phil. Trans. R. Soc. Lond. B. 265, 57-71 (1973)

30) Terai, M., Takenaka, T. and Maeno, H.: Inhibition of calcium influx in rabbit aorta by nicardipine hydrochloride (YC-93). Biochem. Pharmacol. 30, 375-378 (1981) 